\title{
A 型肝炎に伴う腎障害の発症要因に関する検討
}

岡本健鴻野 公伸吉岡 敏治杉本㑆

要旨 $\mathrm{A}$ 型肝炎に伴う腎障害の発症には, B 型肝炎同様, 免疫複合体の関与が強く想定されている が，いまだ明らかではない。その腎障害の原因を解明するため, prospective に臨床的, 組織学的 および免疫学的検討を行った。対象は A 型肝炎の経過中に腎不全の基準を満たした 6 例（男性 6 例, 平均年齢 36.3 歳) である。各症例とも急激に肝炎を発症し, 初発症状出現から 4 ～8 日 (平均 5.6 日）目に近医より搬送された。来院日には全例すでに腎不全状態であった（血清クレアチニン 3.9〜 $19.0 \mathrm{mg} / \mathrm{dl}$, FENa 5.4〜 13.9) が劇症肝炎に至った症例は 1 例のみであった。また高ビリルビ ン血症, レニンーアンギオテンシン系ホルモンの六進, 高尿酸血症はほぼ全例に認められたが, 工 ンドトキシン血症やDIC の合併例はなかった。入院後の経過として, 2 例に血漿交換が施行され, また 4 例には血液透析の施行を一定期間必要としたが, 各症例とも肝機能は急速に正常化し, 腎 機能も来院から 1 力月以内にほほ回復した。腎生検施行例は 5 例であり, 第 12〜38病日 (平均第 24.2 病日)に施行された。腎組織像では, 糸球体変化はきわめて軽度であり, PAM および PAS 染 色法にても係蹄の肥厚はまったく認められなかった。これに対し, 尿細管変化は全例著明であり, 急性尿細管壊死またはその回復所見が観察された。免疫学的検討では, 免疫複合体は全例陰性で あり，明らかな補体低下を来した症例もなかった。蛍光抗体法による免疫グロブリン，補体，フ イブリノゲンの腎組織への沈着はまったく認められなかった。以上, 腎機能の急激な増悪と速や かな回復という臨床経過と組織学的および免疫学的所見より, 自験全例において腎障害は尿細管 壇死による可逆的な急性腎不全であったと結論した。また, 免疫複合体の関与は証明し得なかっ た。

（日救急医会誌 $1994 ； 5 ： 129-36$ )

キーワード：A 型肝炎，腎不全，免疫複合体，急性尿細管壊死

ウイルス性肝炎による腎障害としては，B 型肝炎 ウイルス (以下 HBV と略す) の持続感染によって生 じる腎糸球体障害, いわゆる HBV 腎症がよく知ら れている。その発症機序には免疫複合体が強く関与 し, その病変は系球体係蹄に免疫複合体が沈着して 生じる膜性腎症，または膜性増殖性腎炎とされてい

Pathogenesis of renal insufficiency complicating hepatitis A infection-A clinical study of 6 cases大阪大学医学部救急医学

著者連絡先：干 660 尼崎市稲葉荘 3-1-69 関西労災病院重症治療部

原稿受理日：1993 年 8 月 2 日 （93-053）
る1)。一方, A 型肝炎ウイルス (以下 HAV と略す) についても，A 型肝炎経過中に腎不全を併発し，病 態が重篤化する例があることが，散見する症例報告 から知られるようになった。その腎障害の原因につ いては B 型肝炎同様, 免疫複合体の関与が想定され ているが，いまだ明らかではない。

われわれは，A 型肝炎に伴う腎障害の原因を解明 するため, 自験 6 症例に対し臨床的, 組織学的抢よ び免疫学的検討を行った。その結果，腎障害は全例 において尿細管壊死による可逆的な急性腎不全であ ると結論された。また，免疫複合体の関与は証明し 得なかった。 
Table 1. Laboratory tests on admission day.

\begin{tabular}{|c|c|c|c|c|c|c|c|c|c|c|c|c|c|}
\hline No & $\begin{array}{l}\text { GPT } \\
(\mathrm{IU} / 1)\end{array}$ & $\begin{array}{l}\text { T. bil } \\
(\mathrm{mg} / \mathrm{ml})\end{array}$ & $\begin{array}{l}\text { Creatinine } \\
(\mathrm{mg} / \mathrm{dl})\end{array}$ & $\mathrm{FENa}$ & $\begin{array}{c}\text { Platelets } \\
\left(\times 10^{4} / \mathrm{mm}^{3}\right)\end{array}$ & $\begin{array}{l}\text { PT } \\
(\%)\end{array}$ & $\begin{array}{c}\text { FDP } \\
(\mu \mathrm{g} / \mathrm{ml})\end{array}$ & $\begin{array}{c}\text { Uric } \\
\text { acid } \\
(\mathrm{mg} / \mathrm{dl})\end{array}$ & $\begin{array}{l}\text { Endo- } \\
\text { toxin } \\
(\mathrm{pg} / \mathrm{dl})\end{array}$ & $\begin{array}{l}\text { PRA } \\
(\mathrm{ng} / \\
\mathrm{ml} / \mathrm{hr})\end{array}$ & $\begin{array}{l}\mathrm{C} 3 \\
(\mathrm{mg} / \\
\mathrm{m} l)\end{array}$ & $\begin{array}{l}\mathrm{C} 4 \\
(\mathrm{mg} / \\
\mathrm{ml})\end{array}$ & $\begin{array}{l}\text { Immune } \\
\text { complexes } \\
(\mu \mathrm{g} / \mathrm{ml})\end{array}$ \\
\hline 1 & $3,056 \uparrow$ & $3.5 \uparrow$ & $10.9 \uparrow$ & $13.9 \uparrow$ & 13.9 & 80 & $<5$ & & 0.0 & $5.2 \uparrow$ & & & \\
\hline 2 & $2,436 \uparrow$ & $11.2 \uparrow$ & $19.0 \uparrow$ & $9.4 \uparrow$ & $8.7 \downarrow$ & 120 & $<5$ & & 1.2 & $<0.5$ & 85 & 36 & \\
\hline 3 & $3,296 \uparrow$ & $5.0 \uparrow$ & $7.1 \uparrow$ & $7.2 \uparrow$ & 13.2 & 78 & $<5$ & $14.7 \uparrow$ & & $5.1 \uparrow$ & 60 & 16 & 2.1 \\
\hline 4 & $1,802 \uparrow$ & $6.0 \uparrow$ & $3.9 \uparrow$ & $5.4 \uparrow$ & 10.6 & $20 \downarrow$ & $20 \uparrow$ & $10.9 \uparrow$ & & $2.4 \uparrow$ & 52 & 11 & $<1.0$ \\
\hline 5 & $4,240 \uparrow$ & $14.5 \uparrow$ & $11.9 \uparrow$ & $11.3 \uparrow$ & $9.6 \downarrow$ & $29 \downarrow$ & 10 & $12.9 \uparrow$ & 0.3 & $11.0 \uparrow$ & 87 & 21 & $<1.0$ \\
\hline 6 & $7,490 \uparrow$ & $8.5 \uparrow$ & $11.6 \uparrow$ & $9.4 \uparrow$ & 14.0 & $38 \downarrow$ & $40 \uparrow$ & $25.4 \uparrow$ & 1.2 & $12.5 \uparrow$ & $12 \downarrow$ & 17 & 2.5 \\
\hline
\end{tabular}

\section{症例と方法}

対象症例は，1987 年から 1992 年にかけて大阪大 学医学部附属病院特殊救急部に搬送された $\mathrm{A}$ 型肝 炎症例のうち，肝炎経過中に腎不全を併発した 6 例 である。全例男性であり，平均年齢は 36.3 歳であっ た。A 型肝炎は来院日の IgM 型 HA 抗体陽性によ り診断した。なお，経過中の HBs 抗原および HCV 抗体は全例陰性であった。腎不全の判定基準として は，Wilkinson ら 2) が示した劇症肝炎に合併する腎 不全の基準を参考にし，

1. 血清クレアチニン $2.0 \mathrm{mg} / \mathrm{d} 1$ 以上

2. BUN $60 \mathrm{mg} / \mathrm{dl}$ 以上

3. 尿量 $500 \mathrm{ml} /$ day 以下

のいずれかを満たすものとした。腎疾患の既往例は なかった。

各症例について，一般肝腎機能の経日的測定のほ か, 血中エンドトキシン, レニンーアンギオテンシン 系ホルモンの測定を行った。組織学的検討として， 承諾の得られた症例の腎生検により, HE, PAS およ び PAM の 3 種類の染色法による腎組織標本を作成 した後，光学顕微鏡で観察した。免疫学的検討とし て， Clq 法による血中免疫複合体濃度，補体 $\mathrm{C} 3, \mathrm{C} 4$ の測定のほか, 腎組織標本に蛍光抗体法を用い, IgG, IgM, IgA, C3, C4, C1q, フィブリノゲンの腎組織へ の沈着を観察した。
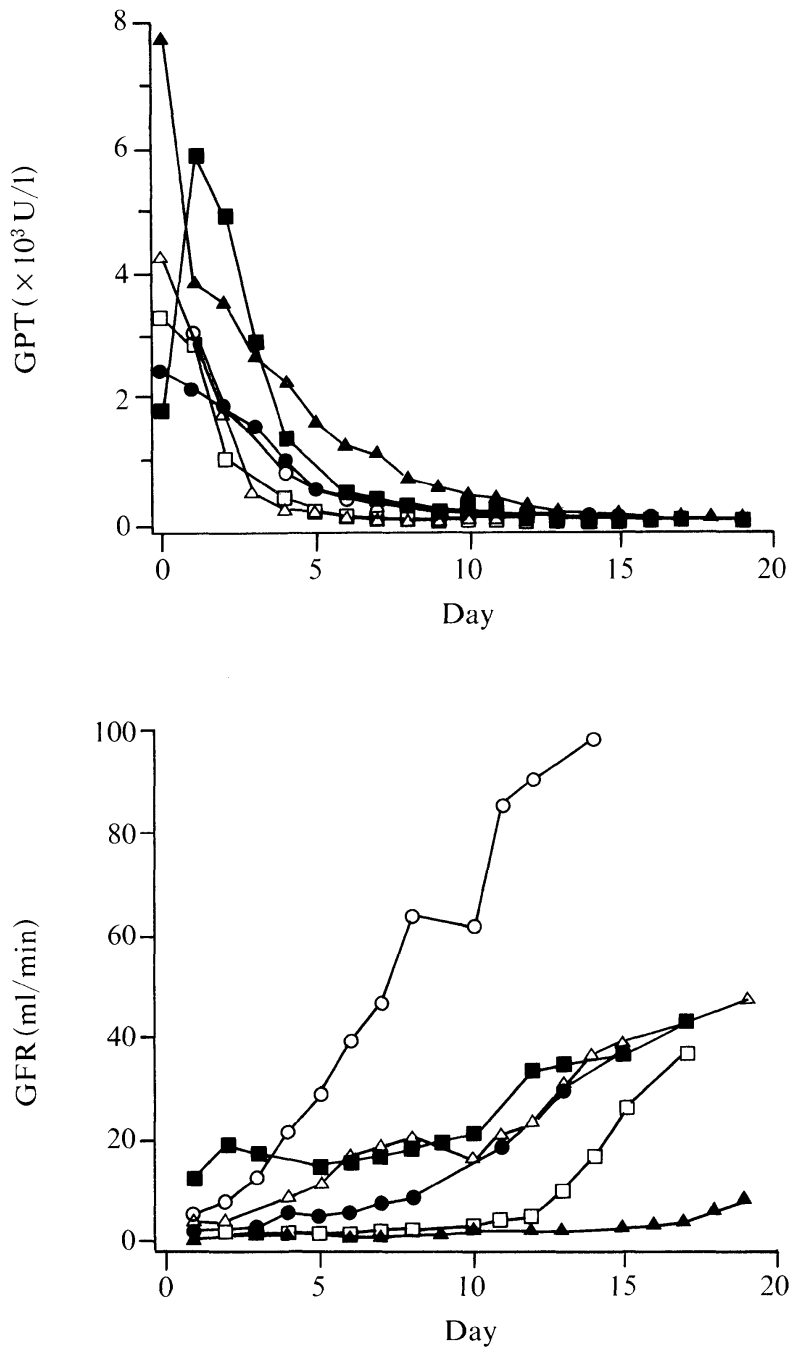

Fig. 1. Daily changes in GPT and GFR (creatinine clearance) after admission.

$\bigcirc=$ case $1 ; \quad=$ case $2 ; \quad \square=$ case $3 ; \quad \square=$ case 4 ;

$\triangle=$ case $5 ; \quad \mathbf{\Delta}=$ case 6 


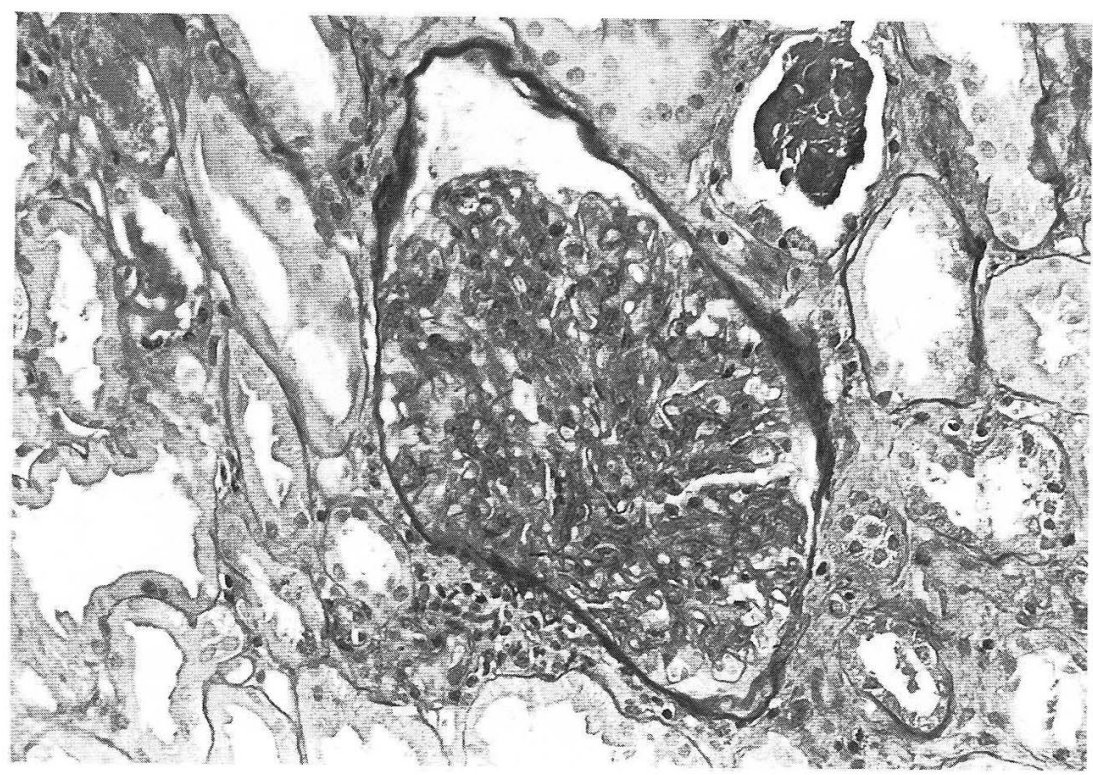

Fig. 2. Renal biopsy specimen from the 18 th hospital day of Case 3 showing a normal glomerulus without abnormal thickening of glomerular capillary walls (light microscopy, PAS stain).

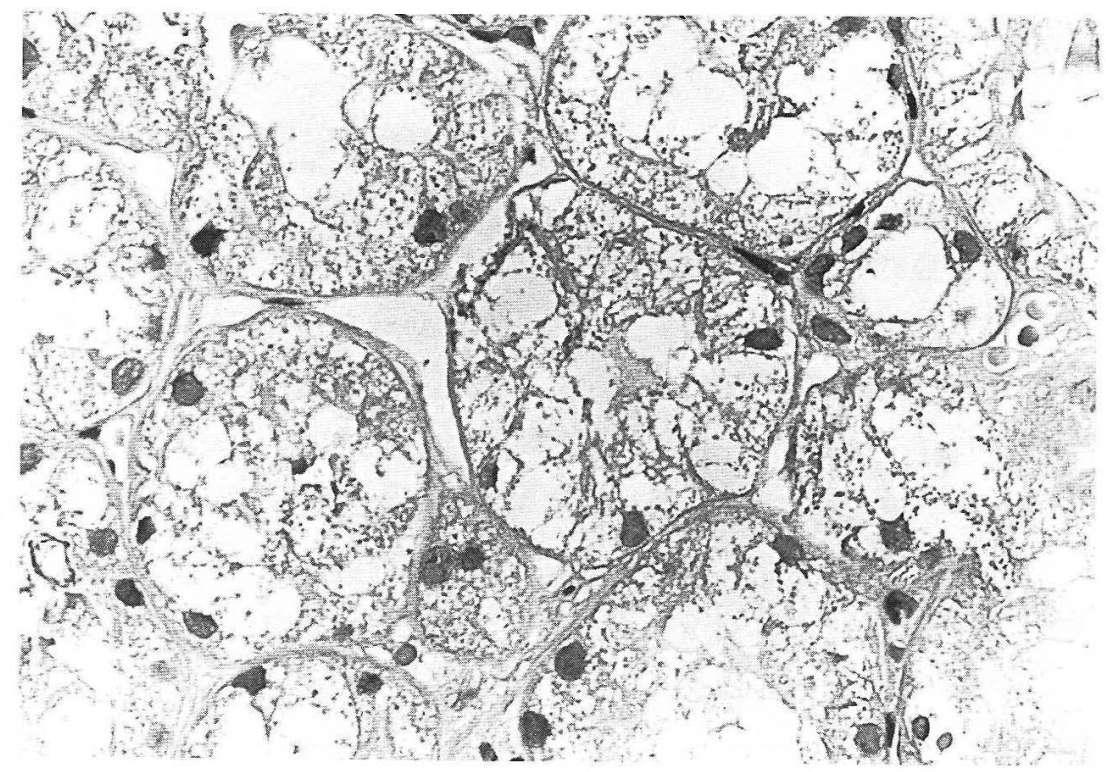

Fig. 3. Renal biopsy specimen from the 12 th hospital day of Case 6 showing typical findings of acute tubular necrosis (light microscopy, HE. stain).

\section{結 果}

\section{1，臨床的検討}

各症例とも発熱，全身倦怠感，悪心，嘔叶，下痢 の症状を伴って急激に発症した。近医にて肝および 腎障害を指摘され, 初発症状出現から 4 8 日(平均
5.6 日)後に特殊救急部に搬送された。特殊救急部米 院日の肝逸脱酵素の著しい高值 (Table 1) より, 全例 重症型肝炎と診断されたが, 経過中に劇症肝炎の診 断基準を満たしたものは症例 5 のみであった。血清 クレアチニンと FENa はいずれも高值を示し，全 6 例とも来院時にはすでに腎不全の状態にあった。ま 


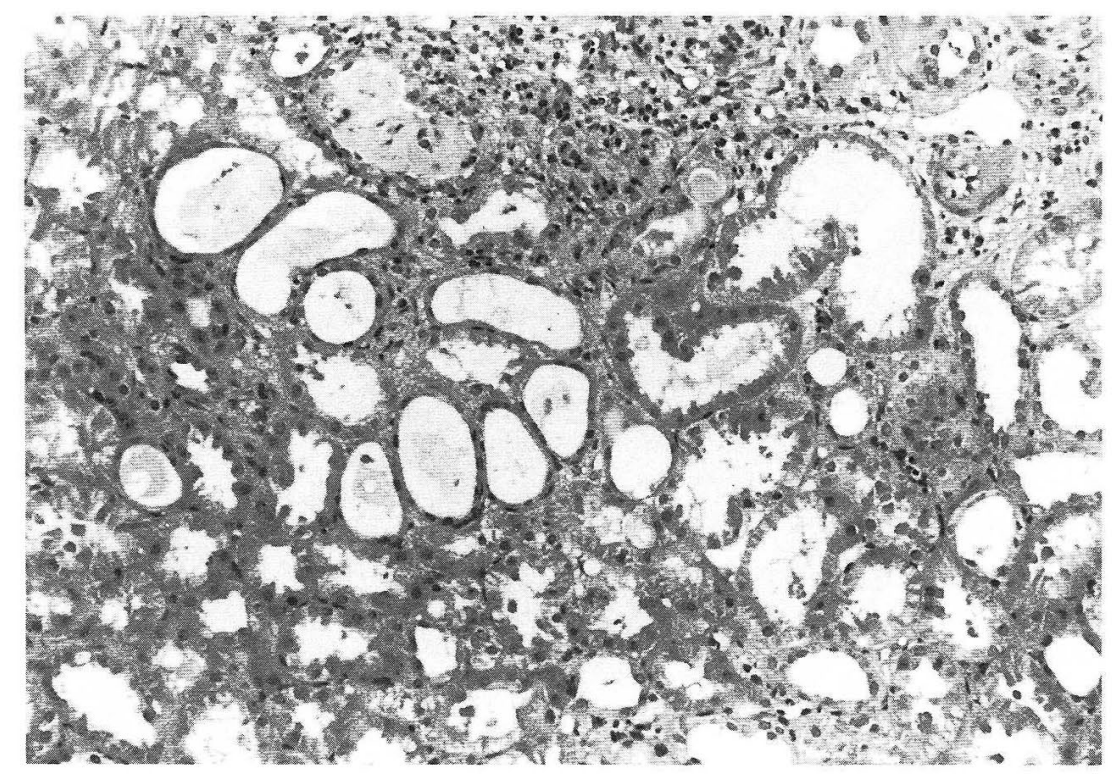

Fig. 4. Renal biopsy specimen from the 24 th hospital day of Case 1 showing recovery findings of acute tubular necrosis (light microscopy, H. E. stain).

た高ビリルビン血症は 6 例中 6 例に, レニンーアンギ オテンシン系の克進は 6 例中 5 例に, 高尿酸血症は 検索した 4 例中 4 例に認められたが，エンドトキシ ン血症やDIC の合併例はなかった。

各症例の肝腎機能の推移として, GPT と GFR の 経日的変化を Fig. 1 に示す。各症例とも GPT は入院 後 5 日間以内に $100 \mathrm{IU} / 1$ 以下に低下した。血漿交換 施行例は症例 4, 5 の 2 例であり, 入院後早期に症例 4 は計 2 回, 症例 5 は計 3 回施行された。GFRも入 院時は $10 \mathrm{ml} / \mathrm{min}$ 以下と低值を示したが, その後早 期に増加傾向を示した。血液透析施行例は 4 例であ り，うち症例 $2,3,5$ は，それぞれ入院後第 $11,15,19$ 病日以降，血液透析より離脱した。症例 6 は，第 21 病日に上部消化管出血を合併し，改善傾向にあった 腎機能が再度増悪した。その結果，長期間の血液透 析を必要としたが, 第 50 病日以降は血液透析より離 脱した。各症例とも血液透析離脱後に腎障害の再燃 を認めることなく退院した。退院時の尿所見は全例 止常であった。

\section{2. 組織学的検討}

腎生検は, 症例 4 を除く 5 例に施行された。施行 時期は入院後平均 24.2 病日であり, 症例 6 では無尿 期間中の第 12 病日に施行され,他の 4 例では腎機能
回復期に相当した第 21 病日から第 38 病日の間に施 行された。腎組織像では, 糸球体の変化は全例きわ めて軽度であった。糸球体の一部にメサンギウム細 胞や基質の軽度の増加を認めた症例もあったが，糸 球体末梢血管係蹄は全例正常であり, PAM および PAS 染色においても係蹄の肥厚はまったく認めら れなかった（Fig.2）。これに対し，尿細管の変化は全 例明らかであった。無尿期に腎生検を施行した症例 6 では尿細管腔に剝離脱落した上皮細胞や，胞体内 の空胞変性および間質浮腫が広範に認められ，典型 的な急性尿細管壊死の像を呈していた（Fig. 3)。腎 機能回復期に腎生検を施行した他の症例では，尿細 管上皮の剥離脱落は軽度であったが，平低化した上 皮細胞が多数認められ，急性尿細管壊死の回復像の 所見と考えられた (Fig. 4)。その他の所見として，尿 細管腔内にビリルビン色素や尿酸結晶の沈着を認め た症例があった。

\section{3. 免疫学的検討}

来院時に血中免疫複合体濃度を測定し得た 4 例は すべて正常範囲であり，補体も症例 6 の C3 低下以 外は正常範井にあった (Table 1)。蛍光抗体法では, $\mathrm{IgG}, \mathrm{IgM}, \mathrm{IgA}, \mathrm{C} 3, \mathrm{C} 4, \mathrm{Clq}$, フィブリノゲンの腎組 織への沈着はまったく認められなかった。 


\section{考 察}

Combes ら ${ }^{3)}$ が, HBV 感染によって形成される免 疫複合体が糸球体腎炎の原因となることを証明して 以来，幾多の臨床および実験的検討がそれを検証し てきた。HBVによる主たる腎病変は糸球体膜性腎 炎1)であり免疫電顕法では HBe 抗原が IgG や C3 とともに糸球体基底膜上皮側に顆粒状に認められ る。また B 型肝炎では膜性増殖性腎炎の報告もあ り，この場合は分子量の大きい HBs 抗原が関与する と推定されている。以上の病変は, 主として HBVキ ヤリアに認められ, HBV の持続感染により生じると される。

一方, HAV の腎障害についても HBV と同様の機 序で生じるという説が現在最も有力である。動物実 験では, Mathiesen ら ${ }^{4)}$ は A 型肝炎に感染したマー モセット 12 頭中 1 頭の腎に HA 抗原の存在を確認 し，またMorita らう）は同様のマーモセットに増殖 性系球体腎炎を認め, 系球体に免疫グロブリンと補 体の沈着を証明した。河合ら ${ }^{6)}$ は A 型肝炎に急性腎 不全を併発した一症例の腎生検所見に, 免疫グロブ リン, 補体の沈着は証明できなかったが, 系球体係 蹄の部分的肥厚を認め, 免疫複合体の糸球体への沈 着の可能性を示唆した。谷川ら7) は $\mathrm{A}$ 型肝炎症例 においては，他の急性肝炎に比し免疫複合体の検出 される頻度が大であり, しかも IgA 型免疫複合体は A 型肝炎にしか見いだされておらず，免疫複合体が 腎障害の原因である可能性が高いと述べている。

しかし, 今回の検討結果は, これらの免疫複合体 関与説を否定するものであった。

第 1 に, 腎障害が肝炎発症後早期から出現して急 激に増悪し，その後速やかに腎機能が回復した点で ある。自験例では, 肝炎発症から平均 5.6 日目に来 院した時点で全例すでに腎不全の状態であった。そ して，経過中に消化管出血を併発した 1 例を除き， 来院から約 1 力月以内に腎機能はほぼ正常化した。 このような臨床経過は, 糸球体腎炎ではみられず, 急性尿細管壊死の経過を示唆させるものである。自
験例の免疫複合体はすべて陰性であったが，免疫複 合体が少なからず形成されていたにせよ，それが肝 炎発症後早期から急性腎不全を引き起こすほど重度 の糸球体病変を発生させるとは考えにくい。また， そのような糸球体病変によって悪化した腎機能が可 逆的かつ短期間に改善しうるのかきわめて疑問であ る。今回の検討でみられた臨床経過は，われわれの 症例に特異的なものではなく，他の症例報告におい ても同様であった でも肝炎発症後 1 週間以内に腎不全が完成され，入 院後 1〜2 カ月以内に腎機能および尿所見は正常化 している。

第 2 の根拠として, 腎生検を施行した 5 例の腎に 組織学的にも免疫学的にも免疫複合体の沈着による 糸球体病変を証明できなかった点がある。他方，尿 細管変化は全例著明であり，いずれも急性尿細管壊 死またはその回復像の所見を呈していた。これらの 組織学的所見より，自験例の腎障害は急性尿細管壊 死により出現したと結論した。われわれの調べた限 りでは，他の症例報告の腎生検組織像で，糸球体係 蹄の病変と免疫グロブリンや補体の沈着を証明し得 た症例はわずかに 2 例であった。うち 1 例は，今武 ら ${ }^{13)}$ が報告した 39 歳女性であり, 第 41 病日に採取 した腎糸球体係蹄に IgG, IgM, C3d の沈着が確認さ れた。彼らは，この所見から免疫複合体が腎不全の 主要原因であると推定したが，同組織標本には，細 胞脱落, 間質浮腫等の急性尿細管壊死回復所見も認

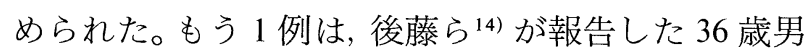
性であり，第 86 病日に採取した腎系球体から IgA の沈着が証明された。しかし，この症例においても 高度の尿細管変性と間質の線維化が同時に確認され た。したがって，これらの症例は, 腎不全の原因が 糸球体病変であったと確定するものではなく, むし ろ, 沈着した免疫グロブリンが長期間組織に残存す ることを証明することで，本研究の腎生検施行時期 に問題がなかったことを示すものである。

このように, 腎機能の急激な増悪と速やかな回復 という臨床経過や組織学的および免疫学的所見よ 
り，自験 6 症例の腎障害の原因はいずれも急性尿細

管壊死であったと結論された。

急性尿細管壊死がいかなる要因で発症したかは明 確ではないが，肝炎発症後早期に腎不全が出現した ことより，肝炎発症に伴う嘔吐，下痢，過剰発汗に よる有効循環血液量の減少が，腎不全の発症要因と して重要であると考えられる。また高ビリルビン血 症, レニンーアンギオテンシン系ホルモンの充進, 高 尿酸血症は，自験例のほぼ全例に肝炎発症後早期か ら認められたが，これらの腎障害因子が急性尿細管 壊死の増悪に関与した可能性は否定できない。Wilkinson ら ${ }^{2,15)}$ は，急性肝障害時のエンドトきシンや それを trigger としたDIC の合併が腎血流の低下を 招き，急性尿細管壊死の発症要因になり得るとして いるが, 今回の検討ではエンドトキシンや DIC の関 与は証明されなかった。いずれにしても $\mathrm{A}$ 型肝炎重 症例では，複数の腎障害因子の関与により，急性尿 細管壞死が容易に発生すると考えられる。

前述したように，A 型肝炎における免疫複合体沈 着性系球体腎炎の可能性を示唆させる多くの文献が ある以上，自験 6 例のみの検討で，それをまったく 否定することはできない。しかし，他の症例報告を みても腎障害の原因が尿細管壊死と推測させるもの が多いのも事実である。

糸球体腎炎か，尿細管壊死かという議論は，単に 病因学的問題ではなく, 当然, 治療法の選択や予後 の評価など臨床上きわめて重要な意味をもつ。例え ば救急医療施設での初期治療上の問題として，A 型 肝炎に伴う腎不全に対して血漿交換が有効とする意 見がある ${ }^{16)}$ 。腎不全が主として免疫複合体の沈着に より発症するという考えから，免疫複合体を含む腎 障害因子の除去を意図したものである。しかし，も し腎不全の本態が免疫複合体の関与しない急性尿細 管壊死であるとすれば，腎不全は血液透析のみで管 理可能である。また，適切な輸液管理によって尿細 管壊死を予防することが，初期治療上最も肝要とな る。

このように臨床的にもきわめて重要な問題である
ため，今後の症例の積み重ねと，さらなる研究を早 急に要すると考えられる。

\section{文献}

1）服部新三郎, 松田一郎：HB ウイルス腎症. 腎と透析 $1985 ； 19: 942-4$.

2) Wilkinson SP,Blendis LM, Williams R : Frequency and type of renal and electrolyte disorders in fulminant hepatic failure. Br Med J 1974；1：186-9.

3) Combes B, Shorey J, Barrera A, et al : Glomerulonephritis with deposition of Australia antigen-antibody complexes in glomerular basement membrane. Lancet $1971 ; 2: 234-7$.

4) Mathiesen LR, Drucker J, Lorenz D, et al : Localization of hepatitis A antigen in marmoset organs during acute infection with hepatitis A virus. J Infect Dis $1978 ; 138: 369-77$.

5) Morita M, Kitajima $\mathrm{K}$, Yoshizawa $\mathrm{H}$, et al : Glomerulonephritis associated with arteritis in marmosets infected with hepatitis A virus. Br J Exp Pathol $1981 ; 62: 103-13$.

6）河合潔, 富田栄一, 杉原潤一, 他：散発性 $\mathrm{A}$ 型急性 肝炎に合併した急性腎不全の 1 救命例一腎生検施行 例一。 日消病会誌 $1983 ; 80 ： 1345-8$.

7) 谷川久一：A 型肝炎. 日内会誌 $1982 ； 71 ： 579-83$.

8）桑原邦治, 中山真人, 三浦洋, 他：急性 $\mathrm{A}$ 型肝炎に 合併した急性腎不全の 2 症例。腎と透析 1987； $22: 1053-7$.

9）田中美和, 中西公王, 稲月明, 他：A 型肝炎に合併 した急性腎不全の 1 例。内科 $1990 ； 65 ： 779-782$.

10）天木秀一, 森山光彦, 本橋隆, 他 : 急性腎不全を合 併した A 型肝炎の臨床的研究. 日大医誌 1989 ; $48: 343-9$.

11）有田美智子, 重本憲一郎, 藤原淳, 他：急性 $\mathrm{A}$ 型肝 炎を併発した急性腎不全の 2 症例。広島医 1987 ； $40: 583-7$.

12）小山田裕一，竹村俊樹，柴田糺，他：散発性急性 A 型肝炎の経過中にみられた腎障害の 1 例. 日消病会 誌 $1985 ; 82: 2714$.

13）今武真由美, 本橋隆, 天木秀一, 他：白血球，血小 板の減少と急性腎不全を合併した A 型肝炎の 1 例. 日消病会誌 $1990 ； 87 ： 1706-9$.

14）後藤泉, 宗宮信賢, 中村司朗, 他：Non A non B 型 肝炎に合併した急性腎不全の病因学的検討一劇症肝 炎による肝腎症候群との比較一。腎と透析 1985； $19: 617-23$.

15) Wilkinson SP, Arroyo V, Gazzard BG, et al : Relation of renal impairment and haemorrhagic diathesis to endotoxemia in fulminant hepatic failure. Lancet $1974 ; 1: 521-4$.

16) Watanabe $S$, Nomoto $H$, Matsuda $M$, et al : A case 
of acute renal failure associated with type A hepatitis responds dramatically to plasmapheresis. Tokai $\mathbf{J}$ Exp Clin Med 1986;11:1-4.

\section{DISCUSSION}

? ウイルスの種類にかかわらず，重症および劇症 る。本論文はそれらのなかで, A 型肝炎に合併する腎 障害は, 従来多くの人が主張していたように免疫複合 体による糸球体腎炎がその本体ではなく, 何らかの原 因による尿細管壊死がその病態の本体であることを主 張する優れた論文である。

われわれも重症あるいは劇症肝炎の約半数に, 血液 浄化法を必要とする腎不全の合併を認めている。著者 らは A 型肝炎に合併する腎障害の発症原因について は，脱水による腎の有効血流量の減少を重要視してい るが，腎障害発症以前にそれほど高度の脱水があった のであろうか。勿論，その時期は他の医療施設で治療 を受けていたようであるので検討しにくい面があろう と思われるが，その点についてまず意見を伺いたい。

また腎障害の程度を示す検査として FENa を検討 してあるが，われわれの経験では FENa は furosemide を投与していると実際より高值を示す場合が多く，腎 障害の指標とはなりにくいとの結果を得ているが，こ れらの症例で FENa の測定時は furosemide は投与さ れていなかったのであろうか。

最後に，われわれは最近 A 型にしろ，B型にしろ重 症あるいは劇症肝炎の場合にはそのウイルスは, 機序 はまだはっきりしないものの，単に肝のみならず，腎 や膵などの実質臟器に障害を起こすと考えた方がよい ような臨床像を呈することが多いことを経験している が，これらの症例では膵炎はなかったか。また病態と してウイルスそのものが，腎を直接的に障害する可能 性というのは考慮しなくてよいのか意見を伺いたい。

そして著者らも述べているように，A 型肝炎による 腎障害の発症に関しては, 著者らと同様に組織学的, あるいは免疫学的検討を加えたうえで免疫複合体の関 与を主張している研究者も多数いるので, 結果を出す にはさらなる症例の集積が必要であると考えられる。

(千葉大学医学部救急部・集中治療部・平澤 博之)
( ( 1 本論文に対して貴重な御意見, 御質問を賜りま
した葉大学医学部救急部・集中治療部平澤博 之先生に厚く御礼申し上げます。

第 1 の質問「腎障害発症以前に高度な脱水状態があ ったか」であるが，本研究の症例は当院入院前に，一 般病院の一般病棟で経口摂取に加え末梢静脈からの輸 液投与 $500 〜 1,000 \mathrm{ml} /$ day を受けていたことが確認さ れている。前医での輸液および治療内容を検討すると, 当院転送直前まで, 病態の重篤性あるいは乏尿の存在 に気づかなかったものと推察された。以上より, 前医 での正確な水分バランスを求めることは不可能であっ たが, 各症例は少なくとも当院搬送前の $4 \sim 8$ 日間, 脱 水状態に置かれた可能性がある。当院入院時には, 理 学所見上は全例脱水状態であったが，有用な “脱水” の指標がないため論文中にデータとして示せなかっ た。ただし，われわれは水分投与量の不足による循環 血液量の減少を腎尿細管壊死の一因として重要視する が，その原因のすべてと考えるわけではない。なぜな ら，この程度の “脱水” は臨床上さほどまれな現象で はなく，そのすべてが腎尿細管壊死を引き起こすわけ ではないからである。

第 2 の質問であるが，前述したように入院時に全例 脱水状態にあったため，それを増悪する危険性のある furosemide は FENa 測定期間内に投与していない。

第 3 の質問であるが，6例中 4 例に一時的な高 amylase 血症を認めたが, 臨床および画像診断上, 膵炎 の存在は確認していない。また, 肝炎ウイルスが直接 腎を障害する可能性については, 腎尿細管壊死の原因 が不明である以上考慮しなければならない問題である が，今回の検討からは残念ながら評価不能である。し かし，ウイルスが関与しない重度肝障害，たと光ば薬 剤性肝炎等にも腎障害が併発する事実より， A 型肝炎 に伴う腎障害のみがウイルス関与による特異的な病態 (ウイルスの直接的障害や免疫複合体による障害) とす るより,むしろ急性ウイルス性肝炎に伴う急性腎不全 が，いわゆる広義の肝腎症候群の病態（有効循環血液 量の減少やエンドトキシン, レニンーアンギオテンシン 系, プロスタグランジン系等の血管作動性物質の関与 やDICの合併等に含まれると考える方が自然ではな いだろうか。膵炎の併発は確認できなかったが, 重症 あるいは劇症肝炎が腎以外の藏器障害を伴う全身性疾 患であるという指標については，われわれも同様の見 解をもっている。

(岡本) 


\section{ABSTRACT \\ Pathogenesis of Renal Insufficiency Complicating Hepatitis A Infection -A Clinical Study of 6 Cases- \\ Ken Okamoto, Masanobu Kohno, Toshiharu Yoshioka and Tsuyoshi Sugimoto Department of Traumatology and Emergency Medicine, Osaka University Hospital}

Six patients with acute hepatitis A who developed renal failure were studied in order to elucidate the pathogenesis of their renal dysfunction. The patients were admitted to our hospital on the 4-8th day (average, 5.6 days) since the onset of hepatitis symptoms. On admission, all of the patients were suffering from renal failure (serum creatinine $3.9 \sim 19.0 \mathrm{mg} / \mathrm{dl}, \mathrm{FENa} 5.4 \sim 13.9$ ), although their hepatitis was nonfulminant except in one case. Bilirubinemia, uricacidemia and activation of the renin-angiotensin system were common to all patients, but none developed endotoxicemia or DIC. Immune complexes were not detected, and complements did not decrease except in 1 patient. Plasmapheresis was performed in 2 patients and daily hemodialysis in 4 . Both hepatic and renal function in all patients recovered within about one month of admission. A kidney biopsy was performed in 5 patients on the 12 $\sim 38$ th hospital day (average, at 24.2 hospital days). Histological findings revealed slight glomerular changes without abnormal thickening of glomerular capillary walls. In contrast, changes were noted in renal tubules. All biopsy specimens demonstrated acute tubular necrosis or its recovery findings. Immunofluorescence study demonstrated no deposits of immunoglobulin, complements or fibrinogen in the biopsied renal tissues. Rapid aggravation and complete recovery of renal function in our patients suggests the clinical course of acute tubular necrosis rather than that of glomerulonephritis induced by immune complexes, Moreover, the results of our histological and immunological studies showed no evidence that immune complexes play a role in the development of renal failure. These results suggest that renal failure complicating hepatitis A infection may be caused by acute tubular necrosis in many cases.

(JJAAM $1994 ; 5: 129-36$ )

Key Words : hepatitis A, renal failure, immune complex, acute tubular necrosis

Received for publication on August 2, 1993 (93-053) 